\title{
Birth Weight Rather Than Maternal Nutrition Influences Glucose Tolerance, Blood Pressure, and IGF-I Levels in Sheep
}

\author{
MARK H. OLIVER, BERNHARD H. BREIER, PETER D. GLUCKMAN, AND JANE E. HARDING \\ Liggins Institute, Faculty of Medicine and Health Science, University of Auckland, Private bag 92019, \\ Auckland, New Zealand.
}

\begin{tabular}{|c|}
\hline ABSTRACT \\
\hline 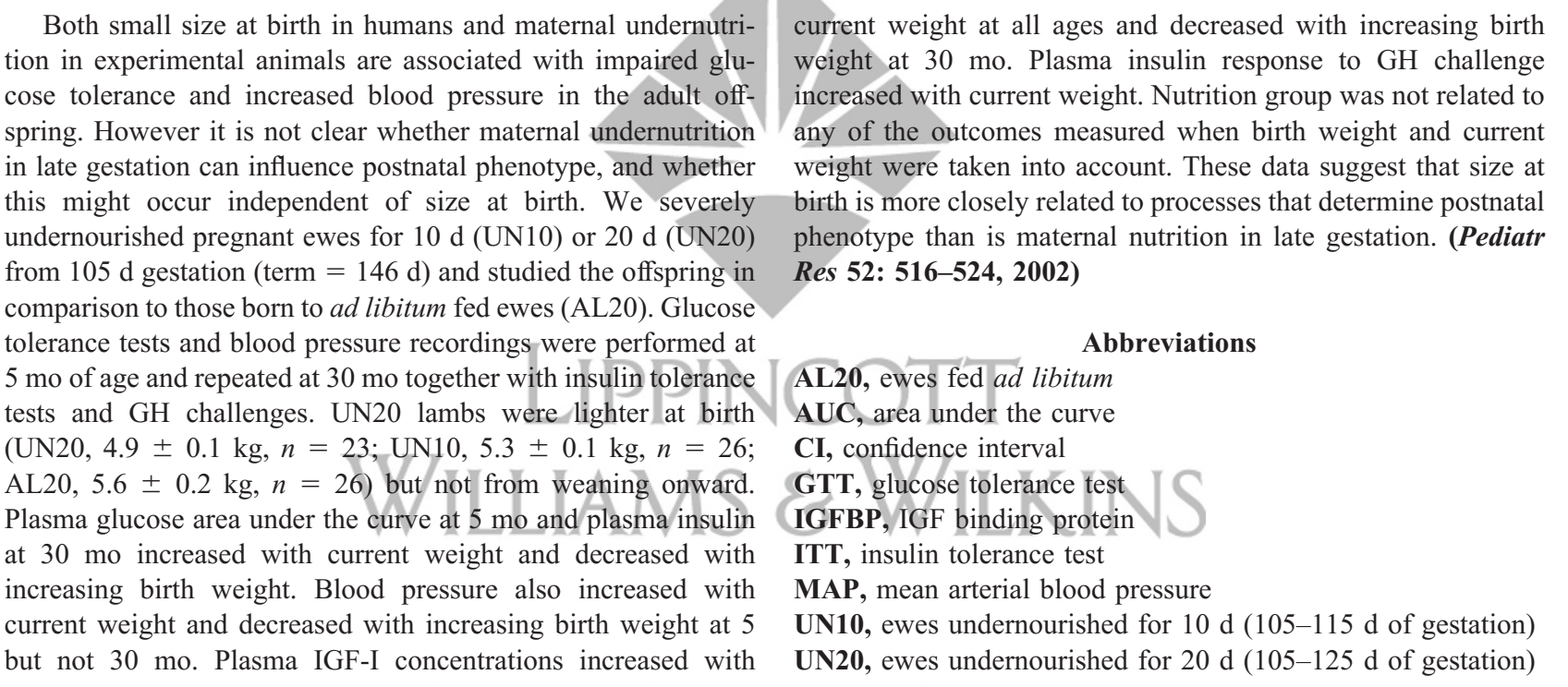 \\
\hline
\end{tabular}

The fetal origins of adult disease hypothesis proposes that small size at birth is associated with a predisposition to metabolic, endocrine, and cardiovascular disease in adult life (1). Epidemiologic studies in human populations have shown that small size at birth is associated with the development of type 2 diabetes and hypertension in adult life $(2-5)$. The reasons for small size at birth are numerous and complex. Studies, particularly in the rodent, demonstrate that both overall maternal undernutrition and protein restriction throughout gestation lead to altered metabolic, endocrine, and cardiovascular function in postnatal life (6-10). Studies of Dutch Hunger Winter survi-

Received July 16, 2001; accepted March 12, 2002.

Correspondence: Mark H. Oliver, Ph.D., Liggins Institute, Faculty of Medicine and Health Science, University of Auckland, Private bag 92019, Auckland, New Zealand; e-mail: m.oliver@auckland.ac.nz

Supported by The Wellcome Trust, Health Research Council of New Zealand, New Zealand Lottery Grants Board, and Auckland Medical Research Foundation, New Zealand.

DOI: 10.1023/01.PDR.0000028852.63989.11 vors suggest that severe maternal undernutrition in pregnant women may also lead to glucose intolerance in their offspring (11).

However a number of questions remain. The favored mechanism to explain the fetal origins of adult disease hypothesis is that an adverse environment, and particularly fetal nutritional demand greater than that supplied by the fetoplacental unit, leads to a series of fetal adaptations. It is proposed that these fetal adaptations to limited nutrient supply result in both reduced fetal growth and permanent changes in structure and function (programming), which in turn lead to predisposition to adult disease $(12,13)$. However, we have shown in sheep that maternal undernutrition can effect marked changes in fetal growth and metabolism without changing overall weight, length, or head circumference of the lamb (14-16). This raises the question of whether programming of postnatal physiologic function can occur without significant change in size at birth. We hypothesized that reduced size at birth is not on the causal pathway between maternal undernutrition and adult disease, 
and therefore that maternal undernutrition in late gestation would result in altered glucose tolerance and blood pressure of the offspring independent of size at birth.

A further question surrounds the possible underlying endocrine mechanisms of programming. It has been proposed that insulin resistance or GH or IGF-I resistance or excessive glucocorticoid exposure, or some combination of these, could all explain the features of the fetal origins syndrome and thus provide a series of unitary underlying mechanisms $(1,12,17$, 18). However, the effect of changes in maternal nutrition on GH or IGF sensitivity in the adult offspring has received little study.

Finally, the timing and duration of maternal undernutrition required to produce postnatal consequences has received limited study, mostly in early gestation (19-23). We have previously shown that maternal undernutrition in the periconceptual period alters growth trajectory and metabolic, endocrine, and cardiovascular regulation in the late-gestation fetal sheep (14, $15,24-26)$. However, the postnatal consequences of varying periods of maternal undernutrition in late gestation have not been determined.

We therefore undertook this long-term study of the effects of maternal undernutrition in sheep. We aimed to distinguish the effects of maternal undernutrition in late gestation from those of birth weight in determining glucose tolerance, blood pressure, and responsiveness to $\mathrm{GH}$ in prepubertal and adult offspring.

\section{METHODS}

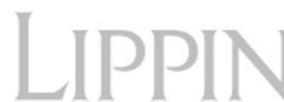

Romney ewes were mated with Dorset rams after synchronization of estrous with the use of intravaginal progesteronerelease devices (27). Ewes were scanned by ultrasound $60 \mathrm{~d}$ after mating, and only those found to be carrying singleton lambs were used for these experiments. Throughout early and mid gestation ewes remained on pasture but received 100 to $200 \mathrm{~g}$ of feed concentrates per day (Multifeed Sheep nuts, NRM Ltd., Auckland, New Zealand) as a supplement and also to aid familiarization to this form of feed. The concentrate diet had $10 \mathrm{MJ}$ metabolizable energy per kilogram (ruminant) and $12.9 \%$ crude protein. At $95 \mathrm{~d}$ of gestation ewes were placed into individual indoor pens, fed the concentrate diet (28), and allowed free access to water and barley straw of low nutritional value.

Ewes were acclimatized indoors for $10 \mathrm{~d}$ before allocation to a treatment group using random number tables. From $105 \mathrm{~d}$ control ewes were fed ad libitum (AL20, approximately 13 and up to $15 \mathrm{MJ} / \mathrm{d}$ at $125 \mathrm{~d}$ ) while restricted ewes were undernourished for either $10 \mathrm{~d}$ (UN10, $0.3 \mathrm{MJ} / \mathrm{d}$ until refeeding at $115 \mathrm{~d}$ ) or $20 \mathrm{~d}(\mathrm{UN} 20,0.3 \mathrm{MJ} / \mathrm{d}$ until $115 \mathrm{~d}$ then $0.5 \mathrm{MJ} / \mathrm{d}$ until refeeding at $125 \mathrm{~d}$ ). Barley straw rations were increased during periods of restriction to provide bulk and maintain rumen function. At $125 \mathrm{~d}$ ewes were returned to supplemented pasture feeding in preparation for lambing.

Soon after birth lambs had their ears tagged, their blood was sampled, they were weighed, and their body proportions were measured. Weights and other measurements were repeated at weaning $(3 \mathrm{mo})$ and at 5 and $30 \mathrm{mo}$ of age. Details of these measurements are available elsewhere (28). At 5 mo lambs (ewes: AL20, $n=11$; UN10, $n=11$; UN20, $n=12$; rams: AL20, $n=7$; UN10, $n=10$; UN20, $n=10$ ) were acclimatized to concentrate feeding in the farm feedlot for approximately $10 \mathrm{~d}$ before being transported into the laboratory for GTTs and blood pressure monitoring.

On arrival at the laboratory lambs were housed in individual metabolic cages with access to water and food ad libitum. Our sheep laboratory has temperature control $\left(16 \pm 1{ }^{\circ} \mathrm{C}\right.$, humidity $50 \pm 10 \%$ ) and a 12-h light-dark cycle. After at least $1 \mathrm{wk}$ of laboratory acclimatization lambs were weighed and fasted the night before surgical implantation of catheters. Antibiotics were administered intramuscularly $(5 \mathrm{~mL}$ of Streptopen, Pitman Moore, Wellington, New Zealand) before the start of surgery. Surgery was performed under general anesthesia (2\% halothane in $\mathrm{O}_{2}$ ). Catheters were placed in a femoral artery and vein, and a subcutaneous catheter was placed under the skin at an equivalent vertical position to the tip of the arterial catheters. Five to $7 \mathrm{~d}$ of recovery was allowed before experiments commenced. Arterial blood pressure and subcutaneous pressure measurements were collected for $12 \mathrm{~h}$ via pressure transducer recording devices (Novotrans II, MX860; Medex, Dublin, OH, U.S.A.). Subcutaneous pressure was used as a zero reference to correct for postural changes and was subtracted electronically. Pressure signals were low-pass filtered at $20 \mathrm{~Hz}$. Pressure data were collected on-line using real-time software according to published methods (29). Lambs were fasted overnight and then injected i.v. with $0.5 \mathrm{~g} / \mathrm{kg}$ body weight glucose. Heparinized blood samples were taken before fasting and -10 , $0,1,3,5,17$, and 10 min from i.v. glucose injection. Lambs were refed after the completion of the sampling. All blood samples were collected on ice, then centrifuged at $3000 \mathrm{rpm}$. Plasma aliquots were stored at $-20^{\circ} \mathrm{C}$ until analysis. Once experiments were completed, the catheters were removed and the lambs were returned to the research farm.

At 30 mo of age ewes ( $n=11$ per group) were bought back into the laboratory for GTT, ITT, blood pressure monitoring, and GH sensitivity testing. Acclimatization, surgical and recovery procedures, and blood pressure monitoring procedures were essentially the same as those described above. From our experience with GTTs at 5 mo we decided to reduce the size of the glucose dose and extend the period of sampling. Ewes were fasted overnight and then injected i.v. with $0.2 \mathrm{~g} / \mathrm{kg}$ body weight glucose. Heparinized blood samples were taken in a fed state and $-10,0,2.5,5,7,10,20,30,40,50,60,90,120,150$, and $180 \mathrm{~min}$ from i.v. glucose injection. Ewes were refed after the completion of the sampling. ITTs were performed approximately $1 \mathrm{wk}$ later using essentially the same sampling protocol with the addition of extra samples taken at 70 and 80 min after i.v. injection of regular insulin $(0.15 \mathrm{U} / \mathrm{kg}$ body weight, $\mathrm{Hu}-$ mulin R; Eli Lilly, Indianapolis, IN, U.S.A.). Blood samples were handled in the manner described above. One week after the ITTs ewes were again fasted overnight before receiving an intramuscular injection of bovine $\mathrm{GH}(\mathrm{bGH}, 0.15 \mathrm{mg} / \mathrm{kg}$ ). Immediately after the injection ewes were refed and further injections of bGH at the same dose were given 12, 24, and $36 \mathrm{~h}$ later. Blood samples were collected before fasting and $-10,0$, $6,12,24,36$, and $48 \mathrm{~h}$ after the first bGH injection. Forty-eight 
hours after the start of GH treatment ewes were euthanized with an overdose of pentobarbitone. Experiments were approved by the Animal Ethics Committee of the University of Auckland.

Assays. Plasma glucose concentration was analyzed using standard enzymatic micromethods modified for 96-well microplates $(30,31)$. Plasma insulin concentrations were measured by an RIA established and validated for ovine plasma in this laboratory. The insulin RIA was identical to our previously published method (32) except that ovine insulin (batch No. 19254; Sigma Chemical Co., St. Louis, MO, U.S.A.) was used as the standard. The standard curve displaced in parallel with ovine plasma samples and cross-reactivity with IGF-I or IGF-II was lower than $0.01 \%$. The minimal detectable concentration was $60 \mathrm{pg} / \mathrm{mL}$ plasma, and the inter- and intraassay coefficients of variation were 11.1 and $6.7 \%$, respectively.

Plasma IGF-I concentrations were measured by IGFBPblocked RIA (33) using a polyclonal antibody (No. 878/4) that has very high affinity and specificity for IGF-I and low crossreactivity with IGF-II $(<0.01 \%)$. Dilution and acidification of plasma to $\mathrm{pH} 2.8$ is followed by addition of excess IGF-II (batch No. 099EM9, $25 \mathrm{ng} /$ tube; Eli Lily) to block IGFBP interference. The RIA exhibits complete parallelism between serial dilutions of ovine plasma and the rhIGF-I standard (No. GO80AB; Genentech, South San Francisco, CA, U.S.A.). The recovery of unlabeled rhIGF-I added before assay was $95 \pm$ $6.6 \%(n=16)$. The $\mathrm{ED}_{50}$ was $0.1 \mathrm{ng} /$ tube, the detection limit was $0.7 \mathrm{ng} / \mathrm{mL}$, and the inter- and intraassây coefficients of variation were 10.1 and $5.0 \%$ respectively.

Plasma IGF-II concentrations were measured using a double-antibody RIA developed for ovine plasma (33). Plasma samples were extracted after an acid-ethanol (AE) cryoprecipitation procedure described previously (34). The standard ovine IGF-II (oIGF-II) was diluted in PBS-Tris-AE buffer $\mathrm{pH}$ 7.6. An hIGF-II antibody (No. P53) raised in this laboratory was used at a final concentration of 1:3600 diluted in assay buffer $(0.05 \mathrm{M}$ sodium phosphate, $0.1 \mathrm{M} \mathrm{NaCl}, 0.2 \% \mathrm{BSA}$, $0.1 \%$ Triton $\mathrm{X}-100,0.05 \% \mathrm{NaN}_{2}, \mathrm{pH} 7.8$ ) containing $37.5 \mathrm{ng}$ of rhIGF-I per $100 \mu \mathrm{L}$ (batch No. 56820A51; Pharmacia, Uppsala, Sweden). Parallel displacement curves between purified ovine IGF-II, rhIGF-II, and serial dilutions of sheep plasma were achieved. The recoveries of oIGF-II in different plasma samples were $88 \pm 7 \%(n=9)$. The minimal detectable concentration of IGF-II was $10 \mathrm{ng} / \mathrm{mL}$ plasma. Inter- and intraassay coefficients of variation were 9.7 and $5.1 \%$, respectively, and cross-reactivity with IGF-I and insulin were $<0.005 \%$.

Plasma oIGFBP-2 concentrations were determined by specific RIA (35). Briefly, bIGFBP-2 (batch No. BP2AU500CJIBP2A2; Gropep, Theburton, Australia) standards and plasma samples were diluted with assay buffer $[0.05 \mathrm{M}$ phosphate buffer, $\mathrm{pH} 7.4,0.1 \mathrm{M} \mathrm{NaCl}, 0.2 \% \mathrm{BSA}$ (Sigma Chemical Co.), $0.1 \%$ Triton $\left.\mathrm{X}-100,0.05 \% \mathrm{NaN}_{3}\right]$. The $\mathrm{ED}_{50}$ for the assay was $0.2 \mathrm{ng}$ of purified oIGFBP-2 per tube, and the minimal detectable dose was $0.05 \mathrm{ng} /$ tube. The inter- and intraassay coefficients of variation were 12 and $6 \%$, respectively.
Statistical analysis. All data are presented as mean \pm SEM. Morphometric data were analyzed using factorial ANOVA with Fisher's correction for post hoc comparisons. MAP data were analyzed as 1-h averages and also after averaging the 12-h collection period. Total AUC was calculated for plasma glucose and insulin responses to GTT. Statistical analysis of treatment group responses during tests was performed using multiple regression with treatment group, birth weight, and current weight as independent variables. Lamb sex was also included as an independent variable up to 5 mo of age. Results of multiple regression analysis are presented in the text as regression coefficients and 95\% CI. StatView 5.0.1 (SAS Institute, Cary, NC, U.S.A.) was used for all statistical analyses.

\section{RESULTS}

UN20 lambs weighed less than AL20 lambs at birth (Table 1 ; all $p<0.05$ ), but body weight was not different among treatment groups at 3,5, or 30 mo of age. A detailed description of maternal feed intake during nutritional manipulations, maternal weight, and fetal and placental morphology is presented in a separate publication (28).

Glucose tolerance. At $5 \mathrm{mo}$, fed and fasted plasma glucose concentrations were not influenced by treatment group, birth weight, current weight, or sex (Table 2). After injection of glucose, plasma glucose AUC was not influenced by treatment group (Fig. 1) but increased with current weight $(+1.58$ $\mathrm{mM} / \mathrm{kg}$ body weight; $95 \% \mathrm{CI}, 0.7-2.4 ; p<0.001)$ and decreased with increasing birth weight $(-6.0 \mathrm{M} / \mathrm{kg}$ birth weight; $95 \% \mathrm{CI},-11.0$ to $-0.8 \mathrm{mM} ; p<0.05$; Table 3 ). Fed and fasted plasma insulin concentrations were not influenced by treatment group, birth weight, or sex, but both increased with current weight. For every kilogram of weight at $5 \mathrm{mo}$, fed plasma insulin concentrations were $12.3 \mathrm{pM}$ higher $(95 \% \mathrm{CI}$, $4.7-20.0 ; p<0.01$ ), whereas fasted plasma insulin concentrations were $2.9 \mathrm{pM}$ higher $(95 \% \mathrm{CI}, 0.5-5.6 ; p<0.05$; Table 3$)$. Plasma insulin AUC during GTT was not influenced by treatment group, birth weight, current weight, or sex.

At $30 \mathrm{mo}$, fed and fasted plasma glucose concentrations and plasma glucose AUC after glucose bolus were not influenced by treatment group, birth weight, or current weight (Tables 2 and 3 and Fig. 2). Fed plasma insulin concentrations were not influenced by treatment group (Tables 2 and 3), but increased with current weight $(+4.4 \mathrm{pM} / \mathrm{kg}$ body weight; $95 \% \mathrm{CI}$,

Table 1. Effect of nutrition group on growth of offspring

\begin{tabular}{cccc}
\hline & AL20 & UN10 & UN20 \\
\hline Ewes (kg) & & & \\
Birth & $5.6 \pm 0.2(13)$ & $5.1 \pm 0.2(13)$ & $4.8 \pm 0.2(13)^{*}$ \\
3 mo $\dagger$ & $28 \pm 1(11)$ & $28 \pm 1(12)$ & $27 \pm 1(12)$ \\
5 mo & $28 \pm 1(11)$ & $29 \pm 2(11)$ & $27 \pm 1(12)$ \\
$30 \mathrm{mo}$ & $74 \pm 2(11)$ & $72 \pm 2(11)$ & $69 \pm 2(11)$ \\
Rams & & & \\
Birth & $5.3 \pm 0.4(10)$ & $5.5 \pm 0.2(13)$ & $5.0 \pm 0.2(13)$ \\
3 mo & $30 \pm 1(8)$ & $29 \pm 1(12)$ & $29 \pm 1(13)$ \\
5 mo & $33 \pm 1(8)$ & $31 \pm 1(10)$ & $29 \pm 2(10)$ \\
\hline
\end{tabular}

Values are mean \pm SEM. Brackets contain number of animals at each time.

* Significantly different from AL20 $(p \leq 0.05)$.

$\dagger$ Sex difference (rams $>$ ewes, $p<0.05$ ). 
Table 2. Effect of treatment on fed and fasted plasma glucose and insulin concentrations in ewes

\begin{tabular}{|c|c|c|c|c|}
\hline \multirow[b]{2}{*}{ Group } & \multicolumn{2}{|c|}{ Glucose (mM) } & \multicolumn{2}{|c|}{ Insulin (pM) } \\
\hline & Fed & Fasted & Fed & Fasted \\
\hline \multicolumn{5}{|l|}{5 mo pre-GTT } \\
\hline AL20 (11) & $4.1 \pm 0.1$ & $3.7 \pm 0.1$ & $120 \pm 20$ & $20 \pm 10$ \\
\hline UN10 (11) & $4.3 \pm 0.2$ & $3.9 \pm 0.2$ & $160 \pm 30$ & $30 \pm 10$ \\
\hline UN20 (12) & $4.3 \pm 0.2$ & $3.7 \pm 0.1$ & $150 \pm 40$ & $30 \pm 10$ \\
\hline \multicolumn{5}{|c|}{30 mo pre-GTT } \\
\hline AL20 (11) & $3.5 \pm 0.1$ & $3.3 \pm 0.1$ & $70 \pm 10$ & $40 \pm 10$ \\
\hline UN10 (11) & $3.5 \pm 0.1$ & $3.1 \pm 0.0$ & $90 \pm 10$ & $40 \pm 10$ \\
\hline UN20 (11) & $3.6 \pm 0.1$ & $3.4 \pm 0.1$ & $100 \pm 20$ & $50 \pm 10$ \\
\hline \multicolumn{5}{|l|}{30 mo pre-ITT } \\
\hline AL20 (11) & $3.5 \pm 0.1$ & $3.3 \pm 0.1$ & $80 \pm 10$ & $40 \pm 10$ \\
\hline UN10 (11) & $3.3 \pm 0.1$ & $3.2 \pm 0.1$ & $60 \pm 10$ & $40 \pm 10$ \\
\hline UN20 (11) & $3.5 \pm 0.1$ & $3.2 \pm 0.1$ & $80 \pm 10$ & $40 \pm 10$ \\
\hline
\end{tabular}

Values are mean \pm SEM. Numbers in brackets represent number of animals studied. There are no significant differences among treatment groups.
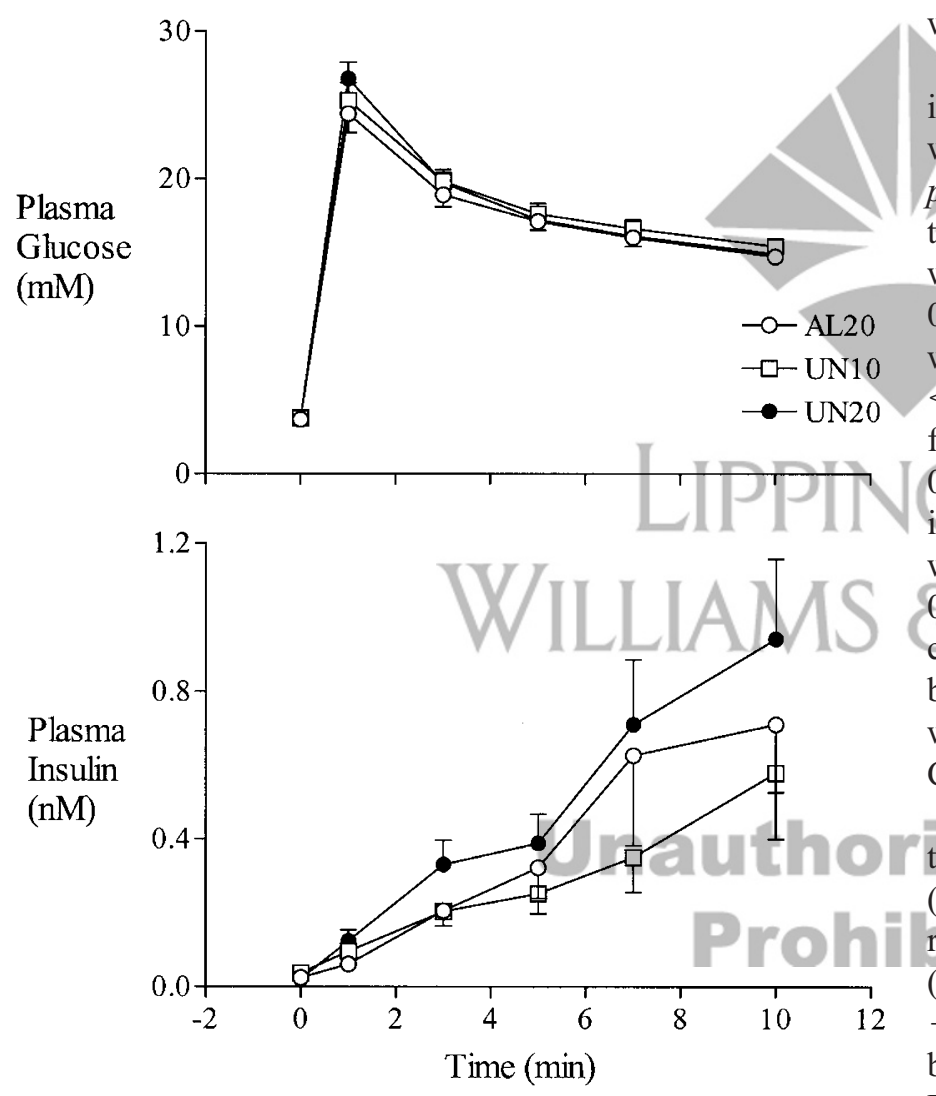

Figure 1. Plasma glucose (top) and insulin (bottom) responses to i.v. GGT $(0.5 \mathrm{~g}$ glucose $/ \mathrm{kg}$ body weight $)$ in 5 -mo-old lambs. Values are mean $\pm \mathrm{SEM}$.

2.0-6.9; $p<0.01)$ and decreased with increasing birth weight $(-35 \mathrm{pM} / \mathrm{kg}$ birth weight; $95 \% \mathrm{CI},-59$ to $-10 ; p<0.01)$. Treatment group, birth weight, or current weight did not influence fasted plasma insulin concentrations (Tables 2 and 3 and Fig. 2) or plasma insulin AUC at 30 mo. However when treatment group, birth weight, and current weight are all included in the analysis, plasma insulin AUC increased with current weight $(+3.5 \mathrm{pM} / \mathrm{kg}$ body weight; $95 \% \mathrm{CI},-0.09$ to $7.1 ; p<0.06)$.

Insulin tolerance. At $30 \mathrm{mo}$, fed and fasted plasma glucose concentrations and fasted plasma insulin concentrations were not influenced by treatment group, birth weight, or current weight (Table 2 and Fig. 3). Fed plasma insulin concentrations were not influenced by treatment group or birth weight but increased with current weight $(+1.9 \mathrm{pM} / \mathrm{kg}$ body weight; $95 \%$ CI, 0.3-3.6; $p<0.05$; Table 2). Plasma glucose and insulin responses to insulin injection were not influenced by current weight. Plasma insulin concentrations were higher in UN20 ewes $2.5 \mathrm{~min}$ after insulin injection $(+959 \mathrm{pM} ; 95 \% \mathrm{CI}$, $357-1561 ; p<0.01)$ but also increased with increasing birth weight $(+524 \mathrm{pM} / \mathrm{kg}$ birth weight; 95\% CI, 71-977; $p<0.05$ ).

Blood pressure. At $5 \mathrm{mo}$, MAP recorded during a 12-h period was not influenced by treatment group (Table 4) or sex, but MAP did increase with current weight $(+0.9 \mathrm{~mm} \mathrm{Hg} / \mathrm{kg}$ body weight; $95 \%$ CI, $0.26-1.5 ; p<0.01$; Table 3) and decreased with increasing weight at birth $(-4.0 \mathrm{~mm} / \mathrm{kg}$ birth weight; $95 \% \mathrm{CI},-7.8$ to $-0.15 ; p<0.05$ ). At $30 \mathrm{mo}$, MAP was not influenced by treatment group, birth weight, or current weight.

GH-IGF axis. Plasma IGF-I concentrations at birth were not influenced by treatment group (Table 4) or sex but increased with birth weight $(+5.2 \mathrm{nM} / \mathrm{kg}$ birth weight; $95 \% \mathrm{CI}, 3.3-7.1$; $p<0.0001$; Table 3). At 3 mo of age, plasma IGF-I concentrations were not influenced by treatment group but increased with current weight $(+1.0 \mathrm{nM} / \mathrm{kg}$ body weight; $95 \% \mathrm{CI}$, $0.53-1.5 ; p<0.0001)$ and decreased with increasing birth weight ( $-2.8 \mathrm{nM} / \mathrm{kg}$ birth weight; $95 \% \mathrm{CI},-5.3$ to $-0.39 ; p$ $<0.05)$. Plasma IGF-I concentrations were higher in male than female lambs at 3 mo $(+8.1 \mathrm{nM} ; 95 \% \mathrm{CI}, 4.8-11.3 ; p<$ 0.0001). Plasma IGF-I concentrations at 5 mo of age were not influenced by treatment group or birth weight but increased with current weight $(+0.69 \mathrm{nM} / \mathrm{kg}$ body weight; $95 \% \mathrm{CI}$, 0.42-0.96; $p<0.0001)$. At 30 mo of age, fed plasma IGF-I concentrations increased with current weight $(+0.29 \mathrm{nM} / \mathrm{kg}$ body weight; 95\% CI, $0.09-0.49 ; p<0.01$ ) and decreased with increasing birth weight $(-2.1 \mathrm{nM} / \mathrm{kg}$ birth weight; $95 \%$ CI, -4.0 to $-0.16 ; p<0.05$; Table 3 ).

At 30 mo plasma IGF-I, IGF-II, and IGFBP-2 responses to the GH stimulation test were not influenced by treatment group (Table 5), birth weight, or current weight. Plasma insulin responses to $\mathrm{GH}$ stimulation increased with current weight $(+6.0 \mathrm{pM} / \mathrm{kg}$ body weight at $6 \mathrm{~h} ; 95 \% \mathrm{CI}, 0.3-11.7 ; p<0.05$; $+62 \mathrm{pM} / \mathrm{kg}$ body weight at $48 \mathrm{~h} ; 95 \% \mathrm{CI}, 8.4-116 ; p<0.05$ ) but were not influenced by treatment group or birth weight. Plasma glucose responses were not influenced by treatment group, birth weight, or current weight.

To clarify the relative magnitude of the interacting effects of birth weight and current weight on outcomes, animals were divided above and below the median for birth weight and current weight. The mean outcome values for each group (higher and lower birth weight, higher or lower current weight) are given in Table 3.

\section{DISCUSSION}

The purpose of this study was to distinguish the effects of maternal undernutrition in late pregnancy, size at birth, and postnatal size on metabolic, endocrine, and cardiovascular regulation during postnatal life. Our main finding was that 
Table 3. Birth weight and current interactions on plasma glucose, insulin, IGF-I, and MAP

\begin{tabular}{|c|c|c|c|c|}
\hline & \multicolumn{2}{|c|}{$\begin{array}{c}5 \text { mo (ewes and rams) } \\
\text { Birth weight }\end{array}$} & \multicolumn{2}{|c|}{$\begin{array}{l}30 \text { mo (ewes) } \\
\text { Birth weight }\end{array}$} \\
\hline & Lower & Higher & Lower & Higher \\
\hline Current weight lower & $4.2 \pm 0.2(17)$ & $4.3 \pm 0.2(14)$ & $3.5 \pm 0.1(11)$ & $3.6 \pm 0.1(5)$ \\
\hline higher & $4.1 \pm 0.1(14)$ & $4.2 \pm 0.1(17)$ & $3.8 \pm 0.1(5)$ & $3.4 \pm 0.1(12)$ \\
\hline \multicolumn{5}{|l|}{ Fasted glucose $(\mathrm{mM})$} \\
\hline Current weight lower & $3.6 \pm 0.1$ & $3.6 \pm 0.1$ & $3.3 \pm 0.1$ & $3.3 \pm 0.1$ \\
\hline Current weight lower & $145 \pm 3 * \dagger$ & $141 \pm 4 * \dagger$ & $951 \pm 30$ & $925 \pm 46$ \\
\hline higher & $157 \pm 3 * \dagger$ & $152 \pm 4 * \dagger$ & $961 \pm 25$ & $952 \pm 25$ \\
\hline \multicolumn{5}{|l|}{ Fed insulin (pM) } \\
\hline Current weight lower & $120 \pm 27 \dagger$ & $135 \pm 26 \dagger$ & $75 \pm 11^{* \dagger}$ & $78 \pm 4^{*} \dagger$ \\
\hline higher & $194 \pm 62 \dagger$ & $154 \pm 22 \dagger$ & $147 \pm 36^{* \dagger} \dagger$ & $73 \pm 7 * \dagger$ \\
\hline \multicolumn{5}{|l|}{ Fasted insulin (pM) } \\
\hline higher & $4.7 \pm 1.2$ & $4.1 \pm 0.8$ & $30 \pm 7$ & $24 \pm 3$ \\
\hline \multicolumn{5}{|l|}{ IGF-I (nM) } \\
\hline Current weight lower & $17 \pm 1 \dagger$ & & $17 \pm 1 * \dagger$ & $16 \pm 1 * \dagger$ \\
\hline higher & $21 \pm 2 \dagger$ & & $21 \pm 1 * \dagger$ & $17 \pm 1 * \dagger$ \\
\hline \multicolumn{5}{|l|}{ MAP (mm Hg) } \\
\hline Current weight lower & $53 \pm 1 * \dagger$ & $52 \pm 3 * \dagger$ & $82 \pm 3$ & $83 \pm 3$ \\
\hline higher & $62 \pm 3 * \dagger$ & $59 \pm 3 * \dagger$ & $83 \pm 3$ & $82 \pm 4$ \\
\hline
\end{tabular}

Animals are divided into groups above and below the median birth weight and current weight at each age (see text for details). Values are mean \pm SEM (number per group for all observations shown in brackets).

* Effect of birth weight $(p<0.05)$.

$\dagger$ Effect of current weight $(p<0.05)$.

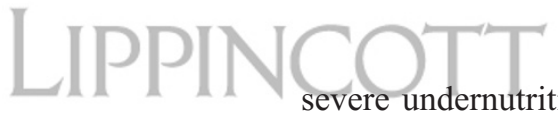
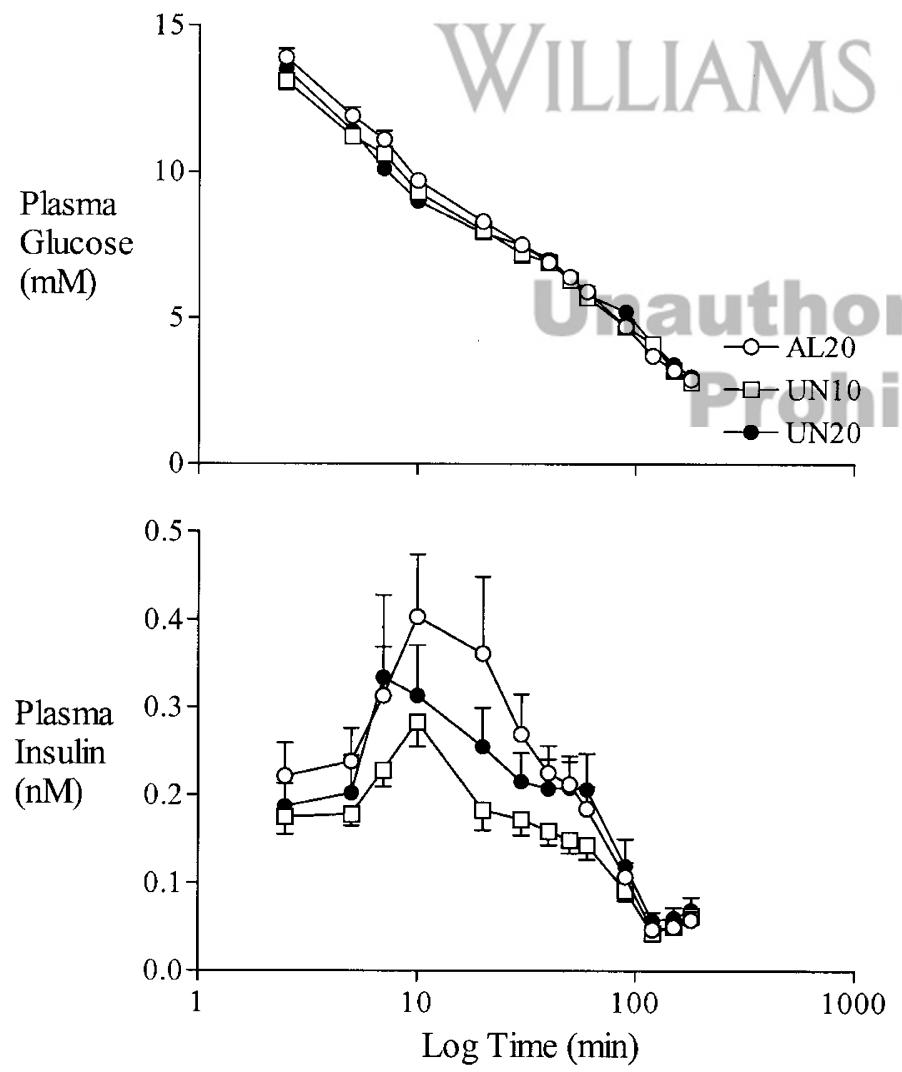

Figure 2. Plasma glucose (top) and insulin (bottom) responses to i.v. GGT ( $0.2 \mathrm{~g}$ glucose $/ \mathrm{kg}$ body weight) in 30 -mo-old ewes. Values are mean $\pm \mathrm{SEM}$. gestation/hăd little effect on glucose tolerance, insulin sensitivity, blood pressure, or IGF-I response to GH in the offspring once birth weight and current weight were taken into account. Furthermore, the negative relationship between birth weight and both glucose tolerance and blood pressure that we observed in 5-mo-old lambs was no longer present in 30-mo-old adult sheep.

Most human studies examining the fetal origins of adult disease hypothesis have studied the relationship between size at birth, usually birth weight or body proportions, and postnatal disease risk factors (1). In contrast, most animal studies have investigated the relationship between maternal nutrition during pregnancy and the physiologic markers of disease risk in their offspring (6-10). However there are limited data from human studies on the direct effects of maternal nutrition on postnatal physiology. The proportions of protein and carbohydrate in the maternal diet during pregnancy have been shown to influence both size at birth (36) and placental size and also blood pressure (37) and insulin resistance (38) in the adult offspring. Studies of survivors of the Dutch famine have also suggested that some of the effects on the offspring of severe maternal undernutrition during pregnancy are independent of size at birth, particularly if the undernutrition occurred in early pregnancy (39). However, in this cohort blood pressure of the offspring was related to size at birth and independent of the presence or timing of maternal undernutrition during gestation (5). 

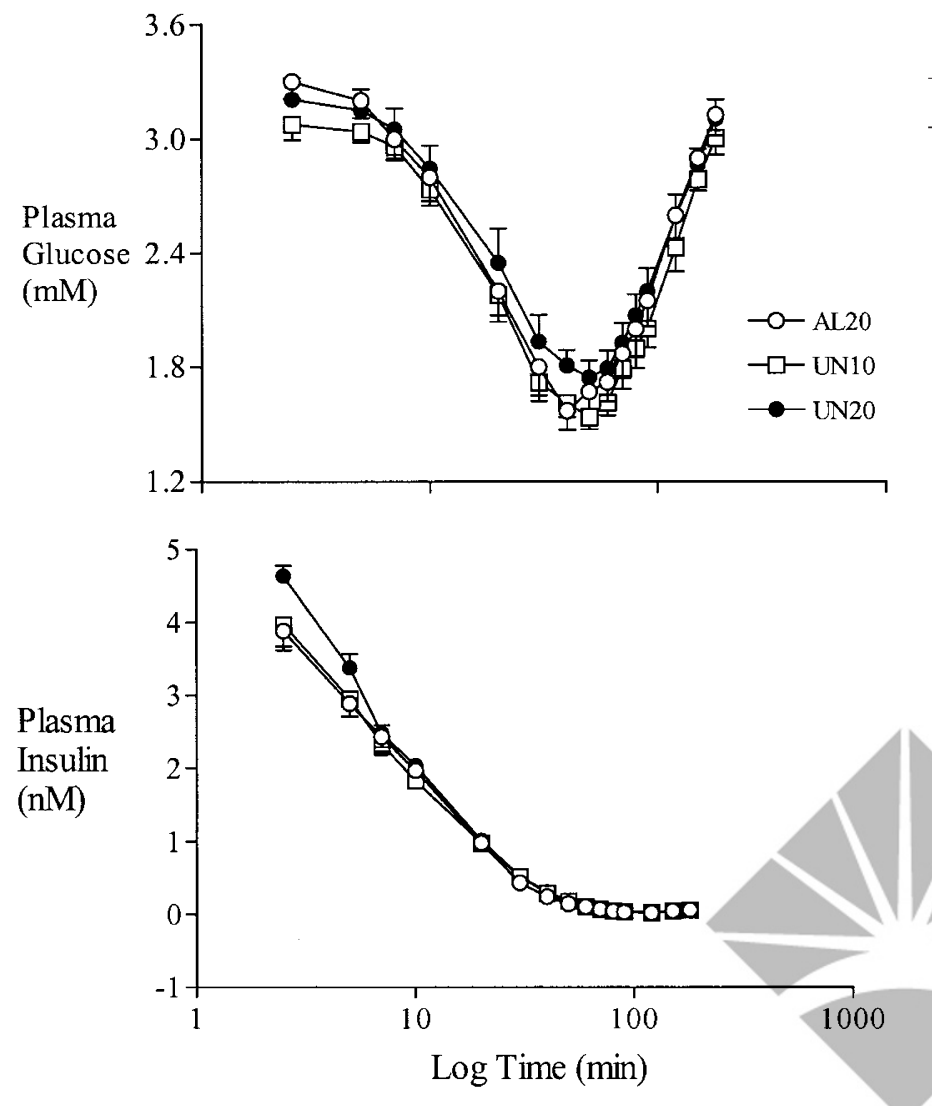

Figure 3. Plasma glucose (top) and insulin (bottom) responses to i.v. ITT $(0.15 \mathrm{U}$ insulin $/ \mathrm{kg}$ body weight) in 30 -mo-old ewes. Values are mean \pm SEM.

Table 4. Effect of nutritional treatment group on plasma IGF concentrations and MAP

\begin{tabular}{|c|c|c|c|}
\hline & AL20 & UN10 & UN20 \\
\hline \multicolumn{4}{|l|}{ Ewes } \\
\hline \multicolumn{4}{|c|}{ IGF-I (nM) } \\
\hline Birth & $20 \pm 2(13)$ & $22 \pm 2(12)$ & $22 \pm 2(12)$ \\
\hline $3 \mathrm{mo}^{*}$ & $23 \pm 1(11)$ & $24 \pm 1(12)$ & $24 \pm 1(12)$ \\
\hline $5 \mathrm{mo}$ & $16 \pm 1(10)$ & $17 \pm 1(9)$ & $17 \pm 1(9)$ \\
\hline $30 \mathrm{mo}$ & $17 \pm 1(11)$ & $18 \pm 1(11)$ & $18 \pm 1(11)$ \\
\hline \multicolumn{4}{|c|}{ MAP (mm Hg) } \\
\hline $5 \mathrm{~m}$ & $53 \pm 3(9)$ & $61 \pm 5(10)$ & $60 \pm 5(10)$ \\
\hline $30 \mathrm{~m}$ & $82 \pm 3(11)$ & $84 \pm 3(11)$ & $81 \pm 3(11)$ \\
\hline \multicolumn{4}{|c|}{ Rams } \\
\hline \multicolumn{4}{|c|}{ IGF-I (nM) } \\
\hline Birth & $26 \pm 2(8)$ & $24 \pm 2(12)$ & $22 \pm 2(12)$ \\
\hline $3 \mathrm{mo}$ & $34 \pm 3(8)$ & $29 \pm 2(12)$ & $34 \pm 3(10)$ \\
\hline $5 \mathrm{mo}$ & $20 \pm 4(6)$ & $17 \pm 2(9)$ & $18 \pm 2(9)$ \\
\hline \multicolumn{4}{|c|}{ MAP (mm Hg) } \\
\hline $5 \mathrm{mo}$ & $59 \pm 6(7)$ & $56 \pm 4(10)$ & $53 \pm 3(10)$ \\
\hline
\end{tabular}

Values are mean \pm SEM. Numbers in brackets represent animals with data obtained at each time point.

* Sex difference $(p<0.0001)$.

It has been proposed that the fetal origins of adult disease reflect fetal adaptive responses in utero to limitation in nutrient supply. These adaptations lead both to altered fetal growth and also to altered physiology, which predisposes to adult disease $(12,13)$. If this proposal is correct, and fetal nutrient limitation does not necessarily lead to altered birth weight, then birth weight is not necessarily on the causal pathway between fetal
Table 5. Effect of nutritional treatment group on plasma endocrine and glucose responses to $48 \mathrm{~h} \mathrm{GH}$ challenge at $30 \mathrm{months}$

\begin{tabular}{cccc}
\hline & AL20 & UN10 & UN20 \\
\hline IGF-I (nM) & & & \\
$0 \mathrm{~h}$ & $15 \pm 1$ & $17 \pm 1$ & $18 \pm 1$ \\
$6 \mathrm{~h}$ & $19 \pm 1$ & $20 \pm 1$ & $20 \pm 1$ \\
$12 \mathrm{~h}$ & $25 \pm 1$ & $27 \pm 1$ & $28 \pm 1$ \\
$24 \mathrm{~h}$ & $42 \pm 2$ & $43 \pm 2$ & $43 \pm 2$ \\
$36 \mathrm{~h}$ & $52 \pm 4$ & $55 \pm 3$ & $53 \pm 2$ \\
$48 \mathrm{~h}$ & $59 \pm 4$ & $60 \pm 3$ & $60 \pm 2$ \\
IGF-II (nM) & & & \\
$0 \mathrm{~h}$ & $21 \pm 2$ & $18 \pm 1$ & $20 \pm 2$ \\
$6 \mathrm{~h}$ & $16 \pm 1$ & $15 \pm 1$ & $16 \pm 1$ \\
$12 \mathrm{~h}$ & $12 \pm 1$ & $11 \pm 1$ & $9.9 \pm 0.6$ \\
$24 \mathrm{~h}$ & $6.6 \pm 0.8$ & $6.1 \pm 0.5$ & $7.2 \pm 0.5$ \\
$36 \mathrm{~h}$ & $5.7 \pm 0.7$ & $4.8 \pm 0.5$ & $5.5 \pm 0.5$ \\
$48 \mathrm{~h}$ & $6.0 \pm 0.8$ & $4.5 \pm 0.6$ & $5.1 \pm 0.5$ \\
IGFBP-2 (nM) & & & \\
$0 \mathrm{~h}$ & $17 \pm 1$ & $15.1 \pm 2$ & $19 \pm 1$ \\
$6 \mathrm{~h}$ & $19 \pm 2$ & $17 \pm 2$ & $22 \pm 2$ \\
$12 \mathrm{~h}$ & $18 \pm 2$ & $16 \pm 2$ & $20 \pm 1$ \\
$24 \mathrm{~h}$ & $15 \pm 2$ & $13 \pm 1$ & $17 \pm 1$ \\
$36 \mathrm{~h}$ & $11 \pm 1$ & $10 \pm 1$ & $13 \pm 1$ \\
$48 \mathrm{~h}$ & $9.0 \pm 0.9$ & $8.4 \pm 0.8$ & $10 \pm 1$ \\
Insulin (pM) & & & \\
$0 \mathrm{~h}$ & $59 \pm 11$ & $57 \pm 8$ & $76 \pm 12$ \\
$6 \mathrm{~h}$ & $206 \pm 33$ & $185 \pm 19$ & $226 \pm 33$ \\
$12 \mathrm{~h}$ & $435 \pm 68$ & $344 \pm 52$ & $425 \pm 52$ \\
$24 \mathrm{~h}$ & $736 \pm 153$ & $1018 \pm 360$ & $964 \pm 194$ \\
$36 \mathrm{~h}$ & $1475 \pm 531$ & $1308 \pm 380$ & $1672 \pm 333$ \\
$48 \mathrm{~h}$ & $1257 \pm 268$ & $1138 \pm 198$ & $1467 \pm 351$ \\
Glucose (mM) & & & \\
$0 \mathrm{~h}$ & $3.3 \pm 0.1$ & $2.4 \pm 0.1$ & $2.4 \pm 0.1$ \\
$6 \mathrm{~h}$ & $3.7 \mathrm{~h}$ & $3.0 \pm 0.1$ & $3.1 \pm 0.2$ \\
$24 \mathrm{~h}$ & $4.0 \pm 0.1$ & $3.6 \pm 0.2$ & $3.9 \pm 0.2$ \\
$36 \mathrm{~h}$ & $4.4 \pm 0.5$ & $4.6 \pm 0.5$ \\
$48 \mathrm{~h}$ & $5.1 \pm 0.5$ & $4.8 \pm 0.5$ & $5.4 \pm 0.6$ \\
\hline
\end{tabular}

Values are mean $\pm \operatorname{SEM}(n=11$ per treatment group). There are no differences between treatment groups.

malnutrition and adult disease (40). This study was specifically designed to address this hypothesis directly. We believe our data are the first to address the effects of maternal nutrition and birth weight independently in determining the effects on the physiology of the offspring.

The findings of this study suggest that birth weight is more important than maternal nutrition in late gestation in determining postnatal glucose tolerance and blood pressure. This was contrary to our expectations, as we have previously argued that important changes in fetal growth, metabolism, and endocrine status may be induced experimentally by maternal undernutrition independently of fetal size $(15,24-26,41)$. We had therefore hypothesized that we would observe an effect of nutrition group on postnatal physiology independent of birth weight. Our data did not support this, and indeed may suggest that birth weight may be on the causal pathway between fetal nutrition and adult disease.

However, these data may also have other explanations. First, we used severe maternal undernutrition for 10 or $20 \mathrm{~d}$ in late gestation to induce fetal undernutrition. Late-gestation nutritional insults are more likely to alter size at birth than are similar insults in early gestation. However, almost all of the 
evidence relating maternal nutrition to postnatal physiology is concerned with altered maternal nutrition in early pregnancy or around the time of conception (42). Indeed, the only other studies of which we are aware demonstrated an association between early gestation undernutrition, postnatal blood pressure (20), and alterations in the hypothalamic-pituitary-adrenal axis in sheep $(21,23)$. Dexamethasone administration to pregnant sheep also results in increased blood pressure of the offspring if given at 27 but not $64 \mathrm{~d}$ gestation, again suggesting the importance of early gestation for the programming phenomenon $(43,44)$. Similarly, the Dutch famine data suggest that it is exposure to famine early in gestation that influences adult health, lipid profile, and coronary heart disease risk (45). Thus further studies may be required to determine the interaction between maternal undernutrition in early pregnancy and birth weight in determining postnatal physiologic function.

Another reason why our findings were not as expected may be that the period of undernutrition was too short. We chose intervals of 10 and $20 \mathrm{~d}$ of undernutrition in late gestation because we had previously shown that a similar 10 -d period of maternal undernutrition results in marked changes in fetal growth and body proportions without altering overall fetal weight (14). When the undernutrition was prolonged to $20 \mathrm{~d}$ we expected that the growth restriction would not be reyersible in utero and that these animals would be small at birth (46). This proved to be the case (28). However, the duration of fetal undernutrition required to induce permanent changes in postnatal physiology is not known. It may be that relatively brief periods of undernutrition in late gestation are not sufficient to permanently reset physiologic and homeostatic-mechanisms and that earlier and/or more prolonged nutritional restriction is required. Furthermore, although our experimental design involved three nutrition groups, there was substantial overlap in birth weight among the groups. Much larger groups may therefore be required to demonstrate relatively subtle effects of brief periods of maternal undernutrition over and above the relatively large effect demonstrated across the range of birth weights in this study.

birth does not lie on the

Finally, it is possible that size at birth does not lie on the
causal pathway between maternal undernutrition and postnatal physiology, but it may nevertheless reflect the underlying programming process more closely than does maternal nutritional group assignment. The assumption that because maternal nutrition may be an important factor determining fetal growth it is also a key factor in the development of adult disease has been challenged (47). We have argued that fetal growth is largely regulated by fetal nutrition in late gestation, but that fetal nutrition may bear little relationship to maternal nutrition (48). This is because a number of steps along the fetal supply line, such as maternal metabolic and endocrine milieu, uterine blood flow, and placental transport capacity, intervene between maternal nutrient intake and fetal nutrient supply. Thus fetal size could be regarded as an indirect integrated measure of fetal nutrient supply, which may bear little relationship to maternal nutrition. If this is so, and if the underlying mechanisms of programming do indeed reflect fetal adaptations to limited nutrient supply, then fetal size may be related more closely than maternal nutrition to the programming mechanism and to postnatal physiologic consequences without lying on the direct causal pathway between the two.

Most epidemiologic studies of the relationship between birth weight and postnatal outcome have taken current weight into account. Although the validity of this has been debated (47), it is widely accepted that current weight is an important influence on both blood pressure and glucose tolerance, particularly in young animals, and that such adjustment is appropriate (4951). We therefore adjusted for current weight in all of our analyses. We found, as expected, that glucose tolerance, blood pressure, and circulating IGF-I concentrations are all strongly positively related to current weight at both postnatal ages studied. Although previous studies have suggested that development of postnatal obesity is an important amplifier of the fetal programming process $(10,11)$, there was no evidence of obesity in our animals. Indeed, we found that the animals whose mothers were undernourished for $20 \mathrm{~d}$ in late gestation tended to have reduced rather than increased back fat depth at 30 mo of age (28). It is therefore unlikely that the development of postnatal obesity, whether related to maternal undernutrition or to birth weight, was an important confounder in the results we observed.

We found the relationships between birth weight and both glucose tolerance and blood pressure that we observed at 5 mo of age were no longer evident when animals were restudied at 30 mo of age. This is in contrast to reports in human studies that these relationships can be demonstrated at all ages except possibly during adolescence (52). Indeed, it has been suggested that the relationships may grow stronger rather than weaker with increasing postnatal age (53). The reason for the discrepancy between our findings and those is not clear. Five-monthold lambs are prepubescent, whereas 30-mo-old ewes are in early adulthood rather than elderly. It would have been interesting to restudy these animals as they aged to determine the possible return of these relationships, but such prolonged study was not possible for logistic reasons. However, future studies in large animals should plan on prolonged follow-up to determine the permanence and possible amplification of any relationships with increasing postnatal age.

For logistic reasons we were unable to keep uncastrated rams on our farm long enough to study at $30 \mathrm{mo}$ of age. It is possible that any effects of birth weight on our outcome measures may have been present in rams but not ewes at 30 mo. The relationship between small size at birth, insulin resistance, and hyperinsulinemia is reported to be present in young adult men but not women (54). However, other studies have demonstrated that small size at birth leads to an exaggerated insulin response to a glucose load in both men and women at $20 \mathrm{y}$ of age (55).

It has been proposed that reduced sensitivity to GH or IGF-I may be a core mechanism by which small size at birth is related to increase blood pressure and impaired glucose intolerance in the offspring $(17,18)$. We found no evidence of altered IGF-I response to GH administration in adult sheep in relation to either maternal nutrition or birth weight. However, plasma IGF-I concentrations were positively related to current weight and negatively related to birth weight in both 5- and 30-mo-old offspring. 
The relationship between birth weight and plasma IGF-I is well established in the human (56) and a number of other species $(57,58)$. Gene knockout studies have demonstrated that IGF-I has a critical role in the regulation of fetal growth (59). The dominant influence of birth weight rather than treatment group on IGF-I concentrations at birth is consistent with this role. In childhood plasma IGF-I concentrations have been reported to be inversely related to birth weight (60). It has been proposed that higher plasma IGF-I levels in children with lower birth weight once current weight is taken into account reflect relative IGF-I resistance in these children. Such an interpretation is also tempting in our studies. It is also possible, although less likely, that the higher IGF-I concentrations in these children simply reflect their more rapid growth, and it is difficult to disentangle these effects in young children or growing lambs. However, the persistence of the negative relationship between birth weight and plasma IGF-I concentrations in adult sheep in our study makes this growth interpretation less likely.

Our GH challenge studies suggest that plasma IGF-I, IGF-II, IGFBP-2, and glucose responses at 30 mo were not influenced by treatment group, birth weight, or current weight. This is consistent with reports that intrauterine growth restricted children have appropriate IGF responses to GH therapy (61). Offspring of rats fed $30 \%$ of ad libitum diet throughout pregnancy also appear to have no impairment in IGF-I response to postnatal $\mathrm{GH}$ treatment despite being smaller at birth (M. Vickers, unpublished observations). Thus, if perturbation of the somatotrophic axis is one possible mechanism for programming of postnatal physiology, it seems likely that GHindependent elements are more involved.

\section{CONCLUSIONS}

In summary, we have shown that severe undernutrition of pregnant ewes for 10 or $20 \mathrm{~d}$ in late gestation has little effect on glucose tolerance or blood pressure of the offspring once birth weight and current weight were taken into account. These findings may suggest that achieved size at birth is more closely related to the programming process than is maternal undernutrition. Our studies provide some evidence of long-term IGF-I insensitivity in lambs of lower birth weight. However, further studies are required to determine the timing and duration of any nutritional insult in pregnancy that results in permanently altered physiology in the offspring.

Acknowledgments. Bovine GH was a gift from Dr. W. Baumbach, Cyanamid. This work would not have been possible without the technical support of Geoff Hobson, Andrzej Surus, Toni Smith-Wong, Samantha Rossenrode, and Sarah Sargison.

\section{REFERENCES}

1. Godfrey KM, Barker DJ 2000 Fetal nutrition and adult disease. Am J Clin Nutr 71(suppl 5):1344S-1352S

2. Hales CN, Barker DJ, Clark PM, Cox LJ, Fall C, Winter PD 1991 Fetal and infant growth and impaired glucose tolerance at age 64. BMJ 303:1019-1022

3. Rich-Edwards JW, Stampfer MJ, Manson JE, Rosner B, Hankinson SE, Colditz GA, Willett WC, Hennekens CH 1997 Birth weight and risk of cardiovascular disease in a cohort of women followed up since 1976. BMJ 315:396-400
4. Rich-Edwards JW, Colditz GA, Stampfer MJ, Willett WC, Gillman MW, Hennekens $\mathrm{CH}$, Speizer FE, Manson JE 1999 Birthweight and the risk for type 2 diabetes mellitus in adult women. Ann Intern Med 130:278-284

5. Roseboom TJ, van der Meulen JH, Ravelli AC, van Montfrans GA, Osmond C, Barker DJ, Bleker OP 1999 Blood pressure in adults after prenatal exposure to famine. J Hypertens 17:325-330

6. Langley-Evans S, Jackson AA 1994 Increased systolic blood pressure in adult rats induced by fetal exposure to maternal low protein diet. Clin Sci (Colch)86:217-222

7. Langley-Evans SC, Gardner DS, Jackson AA 1996 Association of disproportionate growth of fetal rats in late gestation with raised systolic blood pressure in later life. J Reprod Fertil 106:307-312

8. Langley-Evans SC, Gardner DS, Jackson AA 1996 Maternal protein restriction influences the programming of the rat hypothalamic-pituitary-adrenal axis. J Nutr $126: 1578-1585$

9. Langley SC, Browne RF, Jackson AA 1994 Altered glucose tolerance in rats exposed to maternal low protein diets in utero. Comp Biochem Physiol A Physiol 109:223229

10. Vickers MH, Breier BH, Cutfield WS, Hofman PL, Gluckman PD 2000 Fetal origins of hyperphagia, obesity, and hypertension and postnatal amplification by hypercaloric nutrition. Am J Physiol Endocrinol Metab 279:E83-E87

11. Ravelli AC, van der Meulen JH, Michels RP, Osmond C, Barker DJ, Hales CN, Bleker OP 1998 Glucose tolerance in adults after prenatal exposure to famine. Lancet 351:173-177

12. Barker DJP, Gluckman PD, Godfrey KM, Harding JE, Owens JA, Robinson JS 1993 Fetal nutrition and cardiovascular disease in adult life. Lancet 341:938-941

13. Barker DJP 1990 The fetal and infant origins of adult disease. [editorial] BMJ 17:301

14. Harding JE 1997 Periconceptual nutrition determines the fetal growth response to acute maternal undernutrition in fetal sheep of late gestation. Prenat Neonat Med 2:310-319

15. Harding JE, Johnston BM 1995 Nutrition and fetal growth. Reprod Fertil Dev 7:539-547

6. Harding JE, Gluckman PD 2001 Growth, metabolic and endocrine adaptations to fetal undernutrition. In: Barker JDP (ed) Fetal Origins of Cardiovascular Disease and Lung Disease. Marcel Dekker, New York, pp 181-197

17. Gluckman PD, Harding JE 1997 Fetal growth retardation: underlying endocrine mechanisms and postnatal consequences. Acta Paediatr Suppl 422:69-72

18. Gluckman PD, Harding JE 1997 The physiology and pathophysiology of intrauterine growth retardation. Horm Res 48(suppl 1):11-16

19. Kwong WY, Wild AE, Roberts P, Willis AC, Fleming TP 2000 Maternal undernutrition during the preimplantation period of rat development causes blastocyst abnormalities and programming of postnatal hypertension. Development 127:4195-4202

20. Hawkins P, Crowe NA, Clader NA, Saito T, Ozaki T, Stratford LL, Noakes DE, Hansen MA 1997 Cardiovascular development in late gestation fetal sheep and young lambs following modest maternal nutritional restriction in early gestation. J Physiol (Lond) 505:18P (abstr)

21. Hawkins P, Steyn C, McGarrigle HH, Calder NA, Saito T, Stratford LL, Noakes DE, Hansona MA 2000 Cardiovascular and hypothalamic-pituitary-adrenal axis development in late gestation fetal sheep and young lambs following modest maternal nutrient restriction in early gestation. Reprod Fertil Dev 12:443-456

22. Langley-Evans SC, Welham SJ, Sherman RC, Jackson AA 1996 Weanling rats exposed to maternal low-protein diets during discrete periods of gestation exhibit differing severity of hypertension. Clin Sci (Colch) 91:607-615

23. Whorwood CB, Firth KM, Budge H, Symonds ME 2001 Maternal undernutrition during early to midgestation programs tissue-specific alterations in the expression of the glucocorticoid receptor, $11 \beta$-hydroxysteroid dehydrogenase isoforms, and type 1 angiotensin II receptor in neonatal sheep. Endocrinology 142:2854-2864

24. Hawkins P, Oliver MH, Gluckman PD, Harding JE 2000 Periconceptual maternal undernutrition alters fetal growth and length of gestation in sheep. Proceedings of the Fourth Annual Congress of the Perinatal Society of Australia and New Zealand, Parramatta, A43(abstr)

25. Oliver MH, Hawkins P, Gluckman PD, Harding JE 2000 Undernutrition in the periconceptual period influences metabolic responses of fetal sheep to maternal fasting in late gestation. Proceedings of the Fourth Annual Congress of the Perinatal Society of Australia and New Zealand, Parramatta, A92(abstr)

26. Oliver MH, Hawkins P, Breier BH, van Zijl PL, Sargison SA, Harding JE 2001 Maternal undernutrition during the periconceptual period increases plasma taurine levels and insulin response to glucose but not arginine in the late gestation fetal sheep. Endocrinology 142:4576-4579

27. Wheaton JE, Carlson KM, Windels HF, Johnston LJ 1993 CIDR: a new progesteronereleasing intravaginal device for induction of estrus and cycle control in sheep and goats. Anim Reprod Sci 33:127-141

28. Oliver MH, Harding JE, Gluckman PD 2001 Duration of maternal undernutrition in late gestation determines the reversibility of intrauterine growth retardation in sheep. Prenat Neonat Med 6:271-279

29. Williams CE, Gunn AJ, Gluckman PD 1991 Time course of intracellular edema and epileptiform activity following prenatal cerebral ischemia in sheep. Stroke 22:516521

30. Bergmeyer HA 1983 Methods of Enzymatic Analysis, 3 Ed. Verlag Chemie, Weinheim

31. Ashour M-BA, Gee SJ, Hammock BD 1987 Use of a 96-well microplate reader for measuring routine enzyme activities. Anal Biochem 166:353-360

32. Oliver MH, Harding JE, Breier BH, Evans PC, Gluckman PD 1993 Glucose but not a mixed amino acid infusion regulates plasma insulin-like growth factor-I concentrations in fetal sheep. Pediatr Res 34:62-65

33. Blum WF, Breier BH 1994 Radioimmunoassays for IGFs and IGFBPs. Growth Regul 4:11-19 
34. Breier BH, Gallaher BW, Gluckman PD 1991 Radioimmunoassay for insulin-like growth factor-I: solutions to some potential problems and pitfalls. J Endocrinol 128:347-357

35. Gallaher BW, Breier BH, Blum WF, McCutcheon SN, Gluckman PD 1995 A homologous radioimmunoassay for ovine insulin-like growth factor binding protein-2: ontogenesis and the response to growth hormone, placental lactogen and insulin-like growth factor-I treatment in sheep. J Endocrinol 144:75-82

36. Godfrey K, Robinson S, Barker DJ, Osmond C, Cox V 1996 Maternal nutrition in early and late pregnancy in relation to placental and fetal growth. BMJ 312:410-414

37. Campbell DM, Hall MH, Barker DJ, Cross J, Shiell AW, Godfrey KM 1996 Diet in pregnancy and the offspring's blood pressure 40 years later. Br J Obstet Gynaecol 103:273-280

38. Shiell AW, Campbell DM, Hall MH, Barker DJ 2000 Diet in late pregnancy and glucose-insulin metabolism of the offspring 40 years later. Br J Obstet Gynaecol 107:890-895

39. Ravelli AC, van der Meulen JH, Michels RP, Osmond C, Barker DJ, Hales CN, Bleker OP 1998 Glucose tolerance in adults after prenatal exposure to famine. Lancet 351:173-177

40. Hoet JJ, Hanson MA 1999 Intrauterine nutrition: its importance during critical periods for cardiovascular and endocrine development. [review] J Physiol (Lond) 514:617627

41. Harding JE 2001 The nutritional basis of the fetal origins of adult disease. Int J Epidemiol 30:15-23

42. Kwong WY, Roberts P, Wild AE, Langley-Evans SC, Fleming TP 1998 Effect of maternal diet on embryonic development and fetal programming. J Physiol (Lond) 513P:88P(abstr)

43. Dodic M, Wintour EM, Whitworth JA, Coghlan JP 1999 Effect of steroid hormones on blood pressure. Clin Exp Pharmacol Physiol 26:550-552

44. Gatford KL, Wintour EM, De Blasio MJ, Owens JA, Dodic M 2000 Differential timing for programming of glucose homoeostasis, sensitivity to insulin and blood pressure by in utero exposure to dexamethasone in sheep. Clin Sci (Colch) 98:553-560

45. Roseboom TJ, van der Meulen JH, Osmond C, Barker DJ, Ravelli ACJM, van Montfrans GA, Michels RP, Bleker OP 2000 Coronary heart disease after prenatal exposure to the Dutch famine, 1944-45. Heart 84:595-598

46. Mellor DJ, Murray L 1982 Effects of long term undernutrition of the ewe on the growth rates of individual fetuses during late pregnancy. Res Vet Sci 32:177-180

47. Paneth N, Susser M 1995 Early origin of coronary heart disease (the "Barker hypothesis"). BMJ 310:411-412

48. Bloomfield FH, Harding JE 1998 Experimental aspects of nutrition and fetal growth. Fetal Matern Med Rev 10:91-107
49. Whincup PH, Cook DG, Adshead F, Taylor SJ, Walker M, Papacosta O, Alberti KG 1997 Childhood size is more strongly related than size at birth to glucose and insulin levels in 10-11-year-old children. Diabetologia 40:319-326

50. McKeigue PM, Lithell HO, Leon DA 1998 Glucose tolerance and resistance to insulin-stimulated glucose uptake in men aged 70 years in relation to size at birth. Diabetologia 41:1133-1138

51. Bavdekar A, Yajnik CS, Fall CH, Bapat S, Pandit AN, Deshpande V, Bhave S, Kellingray SD, Joglekar C 1999 Insulin resistance syndrome in 8-year-old Indian children: small at birth, big at 8 years, or both? Diabetes 48:2422-2429

52. Huxley RR, Shiell AW, Law CM 2000 The role of size at birth and postnatal catch-up growth in determining systolic blood pressure: a systemic review of the literature. J Hypertens 7:815-831

53. Law CM, Barker DJ 1994 Fetal influences on blood pressure. J Hypertens 12:1329-1332

54. Flanagan DE, Moore VM, Godsland IF, Cockington RA, Robinson JS, Phillips DI 2000 Fetal growth and the physiological control of glucose tolerance in adults: a minimal model analysis. Am J Physiol Endocrinol Metab 278:E700-E706

55. Leger J, Levy-Marchal C, Bloch J, Pinet A, Chevenne D, Porquet D, Collin D, Czernichow P 1997 Reduced final height and indications for insulin resistance in 20 year olds born small for gestational age: regional cohort study. BMJ 315:341347

56. Gluckman PD, Johnson-Barrett JJ, Butler JH, Edgar BW, Gunn TR 1983 Studies of insulin-like growth factor-I and -II by specific radioligand assays in umbilical cord blood. Clin Endocrinol 19:405-413

57. Daughaday WH, Parker KA, Borowsky S, Trivedi B, Kapadia M 1982 Measurement of somatomedin-related peptides in fetal, neonatal, and maternal rat serum by insulin-like growth factor (IGF) I radioimmunoassay, IGF-II radioreceptor assay (RRA), and multiplication-stimulating activity RRA after acid-ethanol extraction. Endocrinology 110:575-581

58. Breier BH, Gluckman PD, Bass JJ 1988 Plasma concentrations of insulin-like growth factor-I and insulin in the infant calf: ontogeny and influence of altered nutrition.

J Endocrinol 119:43-50

59. Baker J, Liu JP, Robertson EJ, Efstratiadis A 1993 Role of insulin-like growth factors in embryonic and postnatal growth. Cell 75:73-82

60. Fall CH, Pandit AN, Law CM, Yajnik CS, Clark PM, Breier B, Osmond C, Shiell AW, Gluckman PD, Barker DJ 1995 Size at birth and plasma insulin-like growth factor-1 concentrations. Arch Dis Child 73:287-293

61. de Zegher F, Maes M, Gargosky SE, Heinrichs CMV, Thiry G, De Schepper J, Craen M, Breysem L, Lofstrom A, Jonsson P, Bourguignon JP, Malvaux P, Rosenfeld RG 1996 High-dose growth hormone treatment of short children born small for gestational age. J Clin Endocrinol Metab 81:1887-1892

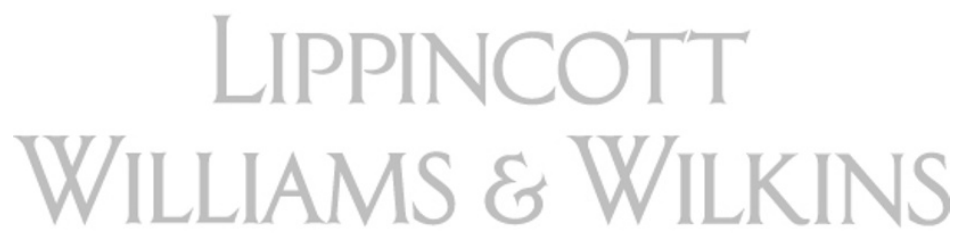

